\title{
Phytotoxicity evaluation of 4-chloro-2-methylphenoxyacetic acid based on ionic liquids and their residues in winter wheat
}

\section{Ocena fitotoksycznego działania cieczy jonowych zawierających anion 4-chloro-2-metylofenoksyoctanowy i ich pozostałości w uprawie pszenicy ozimej}

\author{
Ewa Jakubiak*
}

\section{Summary}

The aim of the study was to evaluate the phytotoxic effects of four new forms of MCPA as a ionic liquids. Herbicidal ionic liquids with MCPA were synthesized at the Chemical Technology Institute of the Poznań University of Technology. As a standard two previously known formulations: potassium-sodium salt and 2-ethylhexyl ester were used. All herbicides were applied at doses of $800 \mathrm{~g}$ active substance per ha. The results showed slight injury symptoms. There wasn't influence on qualitative parameters. No residues of MCPA was found in winter wheat grain.

Key words: ionic liquids; winter wheat; MCPA; phytotoxicity; residues

\section{Streszczenie}

Przedmiotem badań była ocena fitotoksycznego działania czterech nowych form MCPA w postaci cieczy jonowych. Herbicydowe ciecze jonowe (HILs - herbicidal ionic liquids) zsyntezowano w Zakładzie Technologii Chemicznej Politechniki Poznańskiej. Jako standardy zastosowano dostępne w handlu formy MCPA: ester i sól sodowo-potasową. Wszystkie herbicydy zastosowano w dawce 800 g substancji czynnej na ha. Obserwowano niewielkie objawy fitotoksyczności, które nie miały wpływu na parametry jakościowe ziarna. Nie stwierdzono pozostałości MCPA w ziarnie pszenicy ozimej.

Słowa kluczowe: ciecze jonowe; pszenica ozima; MCPA; fitotoksyczność; pozostałości

Instytut Ochrony Roślin - Państwowy Instytut Badawczy

Władysława Węgorka 20, 60-318 Poznań

*corresponding author: ewajakubiak.ior@gmail.com 


\section{Wstęp / Introduction}

Syntetyczne regulatory wzrostu jako herbicydy zostały szeroko rozpowszechnione po drugiej wojnie światowej i do chwili obecnej są powszechnie stosowane w rolnictwie na całym świecie. Środki te przeznaczone są do zwalczania rocznych i wieloletnich chwastów dwuliściennych w uprawach roślin jednoliściennych, głównie zbóż, ale także na trawnikach, polach golfowych, w uprawach leśnych, sadownictwie i na terenach nieużytkowanych rolniczo. Od kilkudziesięciu lat duże zainteresowanie tą grupą związków wynika m.in. z niewielkich kosztów ich stosowania, niskiej toksyczności dla ssaków i krótkiego okresu zalegania w glebie (Zimdahl 1999). Pozytywnymi aspektami stosowania syntetycznych regulatorów wzrostu są również stosunkowo nieliczne przypadki wystąpienia zjawiska odporności chwastów na tę grupę herbicydów. Aktualnie udokumentowano 481 przypadków odporności. Problem ten dotyczy przede wszystkim herbicydów z grupy inhibitorów syntazy acetolaktanowej (ALS - acetolactate synthase inhibitors) - 33\%, natomiast biotypy odporne na herbicydy typu auksyn stanowią 7\% tej liczby (Heap 2017).

Obecnie stosowane formy MCPA to: sól sodowa, potasowa i dimetyloaminowa oraz estry (Praczyk i Skrzypczak 2004; Tomlin 2009). Jedną $\mathrm{z}$ możliwości ograniczenia negatywnych skutków stosowania herbicydów jest ich modyfikacja do postaci cieczy jonowych. Koncepcja syntezy cieczy jonowych zawierających herbicyd powstała W 2007 roku w ramach współpracy Instytutu Ochrony Roślin - Państwowego Instytutu Badawczego z Politechniką Poznańską. Ciecze zawierające herbicydowy anion określono jako herbicydowe ciecze jonowe (HILs - herbicidal ionic liquids) (Pernak i wsp. 2011).

Dotychczas prowadzono badania dotyczące herbicydowych cieczy jonowych zawierających m.in.: dikambę (Cojocaru i wsp. 2013), MCPA (Polit i wsp. 2014), 2,4-D (Pernak i wsp. 2012; Praczyk i wsp. 2012), glifosat (Pernak i wsp. 2014b; Marcinkowska 2017), metsulfuron-metylu (Pernak i wsp. 2015), chlopyralid (Zhu i wsp. 2015). Ponadto zsyntetyzowano ciecze jonowe $z$ fungicydem w anionie (Markiewicz i wsp. 2013), a także środek o podwójnej funkcji, tj. herbicydu i fungicydu (Pernak i wsp. 2014a) oraz herbicydu i regulatora wzrostu (Pernak i wsp. 2013a, b). Istotną cechą herbicydowych cieczy jonowych jest możliwość modyfikacji ich właściwości fizycznych, chemicznych i biologicznych. Ze względu na praktycznie niewyczerpywalne możliwości kombinacji kation-anion, można zaprojektować herbicydowe ciecze jonowe o pożądanych właściwościach, które mogą być alternatywą dla obecnie stosowanych form.

Badania nad nowymi formami MCPA doskonale wpisują się w aktualne regulacje prawne (Ustawa $\mathrm{z}$ dnia 8 marca 2013 r. o środkach ochrony roślin; Rozporządzenie Parlamentu Europejskiego i Rady (WE) nr 1107/2009 z dnia 21 października 2009 r.; Dyrektywa Parlamentu Europejskiego i Rady 2009/128/WE z dnia 21 października 2009 r.), których podstawowym celem jest ograniczenie zagrożeń związanych ze stosowaniem środków ochrony roślin dla zdrowia ludzi, zwierząt oraz środowiska naturalnego.
Celem przeprowadzonych badań była ocena fitotoksycznego działania cieczy jonowych z anionem MCPA $\mathrm{w}$ odniesieniu do roślin pszenicy ozimej.

\section{Materiały i metody / Materials and methods}

Obiektami badań były cztery herbicydowe ciecze jonowe (HILs) zawierające anion 4-chloro-metylofenoksyoctanowy (MCPA - 2-methyl-4-chlorophenoxyacetic acid) zsyntezowane w Zakładzie Technologii Chemicznej Politechniki Poznańskiej oraz dostępne w handlu formy MCPA: ester i sól sodowo-potasowa. Charakterystykę tych związków przedstawiono w tabeli 1. Badania przeprowadzono na terenie Polowej Stacji Doświadczalnej Instytutu Ochrony Roślin - Państwowego Instytutu Badawczego w Winnej Górze (województwo wielkopolskie) w pszenicy ozimej odmiany Ludwig w latach 2010-2011. Doświadczenia założono na poletkach o powierzchni 16,5 $\mathrm{m}^{2}$ w 4 powtórzeniach, w układzie bloków losowanych kompletnych. Zabieg opryskiwania wykonywano w fazie krzewienia pszenicy $(\mathrm{BBCH} 29)$ za pomoca opryskiwacza plecakowego wyposażonego w rozpylacz typu Tee Jet XR 110/03 VP, przy ciśnieniu 0,2 MPa oraz wydajności 200 litrów wody w przeliczeniu na hektar. Intensywność i zakres występowania uszkodzeń roślin wyrażono w procentach $(0 \%$ - brak symptomów fitotoksycznego działania herbicydu, 100\% - całkowite zniszczenie roślin). Wizualną ocenę fitotoksycznego działania zastosowanych związków przeprowadzono po 1, 2, 3 i 4 tygodniach po zabiegu, porównując stan roślin na poletkach traktowanych herbicydami $\mathrm{z}$ roślinami na poletkach kontrolnych (bez herbicydów). Z uwagi na to, że związki HIL 1 oraz HIL 2 są słabo rozpuszczalne w wodzie, a są rozpuszczalne $\mathrm{w}$ mieszaninie wody $\mathrm{z}$ etanolem, $\mathrm{w}$ doświadczeniach zastosowano dwie kontrole: $\mathrm{z}$ wodą oraz $z$ wodą i etanolem $(3: 1)$. Oceniono również wpływ herbicydowych cieczy jonowych na plonowanie i parametry jakościowe ziarna pszenicy ozimej. Pszenicę zbierano $\mathrm{z}$ każdego poletka oddzielnie kombajnem poletkowym Wintersteiger Classic. Ziarno zważono i zmierzono jego wilgotność, następnie przeliczono plon na tony $\mathrm{z}$ hektara przy wilgotności ziarna 14\%. Pomiar analizy jakościowej ziarna (masa hektolitra i zawartość białka) wykonano za pomocą analizatora ziarna Infratec 1241 firmy Foss. Dodatkowo wykonano analizę pozostałości przy zastosowaniu podwójnego systemu detekcji i identyfikacji z wykorzystaniem chromatografu gazowego Varian CP-3800 z detektorem ECD (Electron Capture Detector) oraz spektrometru masowego Saturn 2200 Varian GC/MS (gas chromatography/mass spektrometry). Badania wykonano w Instytucie Uprawy Nawożenia i Gleboznawstwa - Państwowym Instytucie Badawczym, Zakładzie Herbologii i Technik Uprawy Roli we Wrocławiu. Granica wykrywalności pozostałości MCPA zastosowanej metody wynosiła $0,005 \mathrm{mg} / \mathrm{kg}$.

Statystyczne opracowanie wyników oparto na analizie wariancji, szczegółowego porównania średnich dokonano za pomocą testu Tukeya, wyznaczając najmniejszą istotną różnicę na poziomie istotności 5\%. 
Tabela 1. Otrzymane ciecze jonowe

Table 1. Prepared ionic liquids

\begin{tabular}{|c|c|c|c|}
\hline HIL & Ciecz jonowa - Ionic liquids & $\begin{array}{l}\text { Masa molowa } \\
\text { Molar mass }\end{array}$ & $\begin{array}{l}\text { Kation-Anion } \\
\text { Cation-Anion }\end{array}$ \\
\hline 1 & $\begin{array}{l}\text { (4-chloro-2-metylofenoksy)octan didecylodimetyloamoniowy } \\
\text { didecyldimethylammonium (4-chloro-2-methylphenoxy)acetate }\end{array}$ & 526,24 & $\begin{array}{l}62 \% \\
38 \%\end{array}$ \\
\hline 2 & $\begin{array}{l}\text { (4-chloro-2-metylofenoksy)octan dicoco dimetyloamoniowy } \\
\text { dicocodimethylammonium (4-chloro-2-methylphenoxy)acetate }\end{array}$ & 643,57 & $\begin{array}{l}69 \% \\
31 \% \\
\end{array}$ \\
\hline 3 & $\begin{array}{l}\text { (4-chloro-2-metylofenoksy)octan coco trimetyloamoniowy } \\
\text { cocotrimethylammonium (4-chloro-2-methylphenoxy)acetate }\end{array}$ & 445,83 & $\begin{array}{l}52 \% \\
45 \%\end{array}$ \\
\hline 4 & $\begin{array}{l}\text { (4-chloro-2-metylofenoksy)octan coco bis (2-hydroksyetylo) metyloamoniowy } \\
\text { cocodi(2-hydroxyethyl)methylammonium (4-chloro-2-methylphenoxy)acetate }\end{array}$ & 531,61 & $\begin{array}{l}62 \% \\
38 \%\end{array}$ \\
\hline
\end{tabular}

HIL - herbicydowa ciecz jonowa - herbicidal ionic liquid

Dane meteorologiczne dotyczące opadów oraz temperatur zestawiono na podstawie pomiarów wykonanych w stacji meteorologicznej mieszczącej się na terenie Polowej Stacji Doświadczalnej Instytutu Ochrony Roślin - Państwowego Instytutu Badawczego w Winnej Górze. W sezonie 2009/2010 okres jesienny był sprzyjający dla zbóż. Natomiast inaczej kształtowała się sytuacja w sezonie 2010/2011. Niesprzyjające warunki meteorologiczne w okresie jesiennym, tj. intensywne opady deszczu oraz niskie temperatury przyczyniły się do wolniejszego rozwoju rośliny uprawnej, pszenica ozima zakończyła wegetację w fazie 3 liści. Ostra zima, luty bez okrywy śnieżnej oraz silne wiatry spowodowały, że rośliny na początku wegetacji wiosennej charakteryzowały się słabszą kondycją. Warunki meteorologiczne w sezonie wiosennym również były niekorzystne dla zbóż (rys. 1, 2).

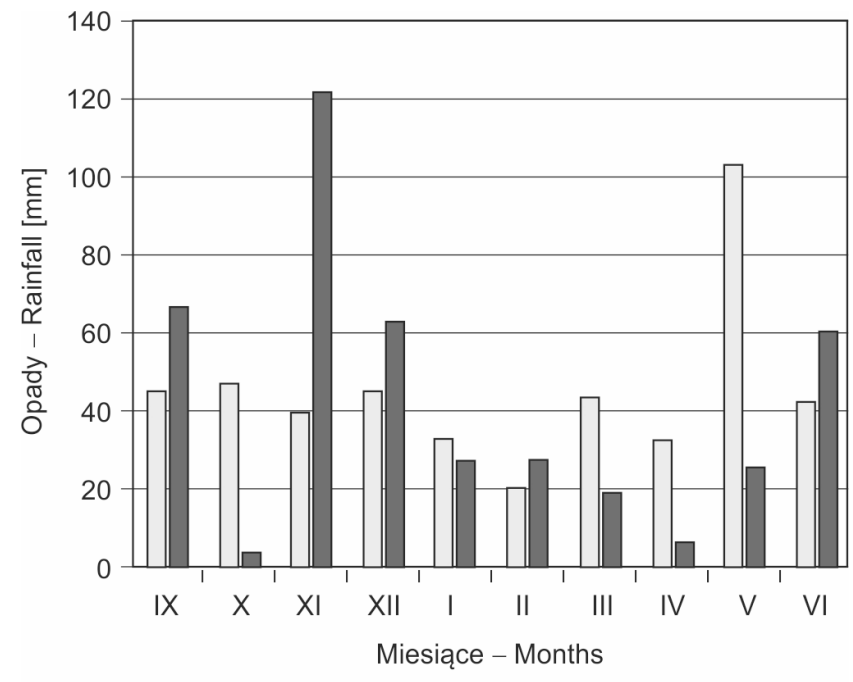

$2009 / 2010$

$2010 / 2011$

Rys. 1. Rozkład miesięcznych opadów atmosferycznych w poszczególnych sezonach badań

Fig. 1. Atmospheric precipitation in the different study seasons

\section{Wyniki i dyskusja / Results and discussion}

Na pszenicy ozimej obserwowano przejściowe objawy fitotoksyczności w postaci nekroz i chloroz, które w roku

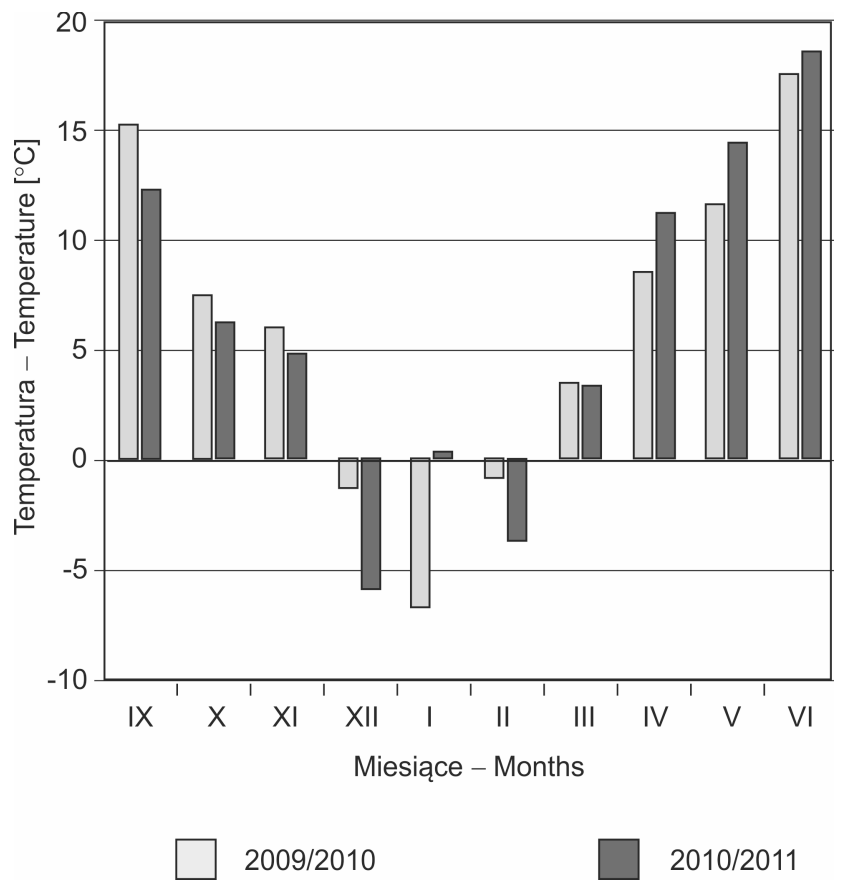

Rys. 2. Średnie dobowe temperatury w sezonie wegetacji pszenicy ozimej w latach 2009-2011

Fig. 2. Average daily temperatures in the winter wheat of growing season 2009-2011

2010 w przypadku zastosowania HIL 2 (tab. 2) oraz w roku 2011 w odniesieniu do obiektu HIL 3 (tab. 3) znalazły odzwierciedlenie w plonowaniu pszenicy ozimej, nie miały jednak istotnego wpływu na parametry jakościowe ziarna (tab. 4). W roku 2010 po zastosowaniu herbicydowych cieczy jonowych wystąpiły uszkodzenia na poziomie $8-16 \%$. Najsilniejsze symptomy obserwowano na obiektach HIL 2 oraz HIL 3. W przypadku herbicydów standardowych obserwowano nekrozy i chlorozy na poziomie 2-3\% (tab. 2). Również w kolejnym roku badań po zastosowaniu HIL wystąpiły niewielkie symptomy fitotoksyczności w granicach 9-14\% (tab. 3). Najsilniejsze uszkodzenia stwierdzono na obiektach HIL 1 oraz HIL 3. Duże zróżnicowanie plonowania pszenicy ozimej w poszczególnych latach było ściśle związane $\mathrm{z}$ warunkami pogodowymi, zwłaszcza opadami (tab. 4, rys. 1). Podobne objawy fitotoksyczności obserwowano w badaniach z HIL 
Tabela 2. Ocena fitotoksycznego oddziaływania herbicydów stosowanych w dawce $800 \mathrm{~g} \mathrm{MCPA} /$ ha na pszenicę ozimą w roku 2010 Table 2. Phytotoxicity evaluation herbicides applied at rate $800 \mathrm{~g}$ MCPA/ha on winter wheat in 2010

\begin{tabular}{c|c|c|c|c|c}
\hline \multirow{2}{*}{$\begin{array}{c}\text { Lp. } \\
\text { No. }\end{array}$} & Obiekt & \multicolumn{3}{|c}{ Liczba dni po zabiegu - Days after application } \\
\cline { 2 - 5 } & Treatment & 7 & 14 & 21 & 0 \\
\hline 1 & kontrola - control (w) & 0 & 0 & 0 & 0 \\
\hline 2 & kontrola - control (w + e) & 0 & 0 & 0 & 0 \\
\hline 3 & HIL 1 (w + e) & 13 & 0 & 0 & 0 \\
\hline 4 & HIL 2 (w+e) & 16 & 0 & 0 & 0 \\
\hline 5 & HIL 3 (w) & 16 & 0 & 0 & 0 \\
\hline 6 & HIL 4 (w) & 8 & 0 & 0 & 0 \\
\hline 7 & MCPA-ester & 2 & 0 & 0 & 0 \\
\hline 8 & MCPA-sól - MCPA-salt & 3 & 0 & 0 \\
\hline
\end{tabular}

HIL - herbicydowa ciecz jonowa - herbicidal ionic liquid; $w$ - woda - water; $w+e$ - woda + etanol $3: 1$ - water + ethanol $3: 1$

Tabela 3. Ocena fitotoksycznego oddziaływania herbicydów stosowanych w dawce $800 \mathrm{~g} \mathrm{MCPA} / \mathrm{ha}$ na pszenicę ozimą w roku 2011

Table 3. Phytotoxicity evaluation herbicides applied at rate $800 \mathrm{~g}$ MCPA/ha on winter wheat in 2011

\begin{tabular}{c|c|c|c|c|c}
\hline \multirow{2}{*}{$\begin{array}{c}\text { Lp. } \\
\text { No. }\end{array}$} & Obiekt & \multicolumn{3}{|c}{ Liczba dni po zabiegu - Days after application } \\
\cline { 2 - 5 } & Treatment & 7 & 14 & 21 & 28 \\
\hline 1 & kontrola - control (w) & 0 & 0 & 0 & 0 \\
\hline 2 & kontrola - control (w + e) & 0 & 0 & 0 & 0 \\
\hline 3 & HIL 1 (w + e) & 14 & 0 & 0 & 0 \\
\hline 4 & HIL 2 (w + e) & 10 & 0 & 0 & 0 \\
\hline 5 & HIL 3 (w) & 12 & 0 & 0 & 0 \\
\hline 6 & HIL 4 (w) & 9 & 0 & 0 & 0 \\
\hline 7 & MCPA-ester & 0 & 0 & 0 & 0 \\
\hline 8 & MCPA-sól - MCPA-salt & 0 & 0 & 0 \\
\hline
\end{tabular}

HIL - herbicydowa ciecz jonowa - herbicidal ionic liquid; $w$ - woda - water; $w$ + e - woda + etanol $3: 1$ - water + ethanol $3: 1$

Tabela 4. Wpływ różnych form MCPA stosowanych w dawce $800 \mathrm{~g}$ substancji czynnej na ha, na plon i wybrane parametry jakościowe ziarna pszenicy ozimej

Table 4. Influence of different form of MCPA applied at rate $800 \mathrm{~g}$ active substance per ha on yield and selected qualitative parameters of winter wheat grain

\begin{tabular}{|c|c|c|c|c|c|c|c|c|c|}
\hline \multirow[b]{2}{*}{$\begin{array}{l}\text { Lp. } \\
\text { No. }\end{array}$} & \multirow[b]{2}{*}{$\begin{array}{l}\text { Obiekt } \\
\text { Treatment }\end{array}$} & \multicolumn{4}{|c|}{2010} & \multicolumn{4}{|c|}{2011} \\
\hline & & $\begin{array}{l}\text { plon } \\
\text { yield } \\
\text { [t/ha] }\end{array}$ & $\begin{array}{l}\text { MTZ } \\
\text { the } \\
\text { thousand } \\
\text { grain } \\
\text { weight } \\
\text { [g] }\end{array}$ & $\begin{array}{c}\text { gęstość } \\
\text { ziarna } \\
\text { grain } \\
\text { density } \\
{[\mathrm{kg} / \mathrm{hl}]}\end{array}$ & $\begin{array}{c}\text { zawartość } \\
\text { białka } \\
\text { protein } \\
\text { content } \\
{[\%]}\end{array}$ & $\begin{array}{l}\text { plon } \\
\text { yield } \\
\text { [t/ha] }\end{array}$ & $\begin{array}{l}\text { MTZ } \\
\text { the } \\
\text { thousand } \\
\text { grain } \\
\text { weight } \\
\text { [g] }\end{array}$ & $\begin{array}{l}\text { gęstość } \\
\text { ziarna } \\
\text { grain } \\
\text { density } \\
{[\mathrm{kg} / \mathrm{hl}]}\end{array}$ & $\begin{array}{c}\text { zawartość } \\
\text { białka } \\
\text { protein } \\
\text { content } \\
\text { [\%] }\end{array}$ \\
\hline 1 & $\begin{array}{c}\text { kontrola - control } \\
\text { (w) }\end{array}$ & 8,64 bc & 54,21 a & 76,93 a & 12,80 a & $5,80 \mathrm{c}$ & 40,61 a & 75,63 a & 11,55 a \\
\hline 2 & $\begin{array}{c}\text { kontrola - control } \\
(\mathrm{w}+\mathrm{e})\end{array}$ & $8,83 \mathrm{c}$ & 53,80 a & 76,41 a & 12,60 a & $5,44 a b$ & 39,0 a & 74,95 a & 11,63 a \\
\hline 3 & HIL $1(w+e)$ & 8,76 bc & 53,82 a & 76,34 a & $12,70 \mathrm{a}$ & $5,51 \mathrm{abc}$ & 41,50 a & 76,25 a & 11,85 a \\
\hline 4 & HIL $2(w+e)$ & $7,91 \mathrm{a}$ & 51,17 a & 76,03 a & $12,33 \mathrm{a}$ & $5,81 \mathrm{c}$ & $41,02 \mathrm{a}$ & 76,08 a & 12,13 a \\
\hline 5 & HIL 3 (w) & $8,51 \mathrm{abc}$ & 53,54 a & 76,13 a & 11,73 a & 5,23 a & 39,05 a & 75,45 a & 12,10 a \\
\hline 6 & HIL 4 (w) & $8,14 \mathrm{ab}$ & 52,50 a & $76,20 \mathrm{a}$ & $11,98 \mathrm{a}$ & 5,59 bc & $40,52 \mathrm{a}$ & 76,0 a & $12,18 \mathrm{a}$ \\
\hline 7 & MCPA-ester & 8,67 bc & 53,56 a & 76,43 a & 12,53 a & $5,37 \mathrm{ab}$ & $41,18 \mathrm{a}$ & 76,23 a & $12,00 \mathrm{a}$ \\
\hline 8 & $\begin{array}{l}\text { MCPA-sól } \\
\text { MCPA-salt }\end{array}$ & 8,70 bc & 53,83 a & 76,63 a & 12,63 a & 5,19 a & 41,64 a & 75,73 a & 11,73 a \\
\hline
\end{tabular}

HIL - herbicydowa ciecz jonowa - herbicidal ionic liquid; w - woda - water; w + e - woda + etanol $3: 1$ - water + ethanol $3: 1$

Wartości oznaczone tymi samymi literami nie różnią się istotnie przy $\alpha=0,05-$ Values marked with the same letters do not differ significantly at $\alpha=0.05$ 
zawierającymi 2,4-D zastosowanymi w dawce 1200 g substancji czynnej na ha, na co mogła mieć wpływ zbyt duża koncentracja kationu w roztworze. Jednak w przypadku 2,4-D nie obserwowano wpływu na plonowanie pszenicy i nie obserwowano uszkodzeń po zastosowaniu herbicydów referencyjnych (Praczyk i wsp. 2012).

Tabela 5. Analiza pozostałości MCPA w ziarnie pszenicy ozimej Table 5. Analyses of residues of MCPA in grain of winter wheat

\begin{tabular}{c|c|c}
\hline \multirow{2}{*}{$\begin{array}{c}\text { Obiekty } \\
\text { Treatments }\end{array}$} & \multicolumn{2}{|c}{$\begin{array}{c}\text { Pozostałości - Residues } \\
{[\mathrm{mg} / \mathrm{kg}]}\end{array}$} \\
\cline { 2 - 3 } & 2010 & 2011 \\
\hline HIL 1 (w+e) & $<0,005$ & $<0,005$ \\
\hline HIL 2 (w+e) & $<0,005$ & $<0,005$ \\
\hline HIL 3 (w) & $<0,005$ & $<0,005$ \\
\hline HIL 4 (w) & $<0,005$ & $<0,005$ \\
\hline MCPA-ester & $<0,005$ & $<0,005$ \\
\hline MCPA-sól - MCPA-salt & $<0,005$ & $<0,005$ \\
\hline
\end{tabular}

HIL - herbicydowa ciecz jonowa - herbicidal ionic liquid

w - woda - water; $\mathrm{w}+\mathrm{e}$ - woda + etanol $3: 1$ - water + ethanol $3: 1$

Ponadto $\mathrm{w}$ próbach ziarna pobranych $\mathrm{z}$ doświadczeń z herbicydowymi cieczami jonowymi zawierającymi MCPA w anionie nie stwierdzono pozostałości MCPA. Uzyskane wyniki były poniżej granicy wykrywalności zastosowanej metody analitycznej (poniżej 0,005 mg/kg), co świadczy o tym, że herbicydowe ciecze jonowe $\mathrm{z}$ anionem MCPA nie stanowią zagrożenia dla zdrowia ludzi i zwierząt (tab. 4). Zgodnie z Rozporządzeniem Komisji
(UE) nr 491/2014 z dnia 5 maja 2014 r. dopuszczalny poziom MCPA w zbożach, w tym w pszenicy wynosi $0,2 \mathrm{mg} / \mathrm{kg}$. Również w badaniach prowadzonych przez Marcinkowską (2017) z herbicydowymi cieczami jonowymi z glifosatem stosowanymi przed żniwami oraz w badaniach z 2,4-D (Praczyk i wsp. 2012) nie stwierdzono pozostałości w ziarnie pszenicy.

\section{Wnioski / Conclusions}

1. Herbicydowe ciecze jonowe $\mathrm{z}$ MCPA w anionie stosowane w dawce 800 g substancji czynnej na ha powodowały niewielkie i przemijające uszkodzenia roślin pszenicy ozimej.

2. Obserwowano istotne w porównaniu do kontroli obniżenie plonu pszenicy ozimej odmiany Ludwig na obiektach z herbicydowymi cieczami jonowymi HIL 2 w roku 2010 oraz HIL 3 w roku 2011. Nie stwierdzono statystycznie istotnych różnic między obiektami w odniesieniu do parametrów jakościowych ziarna.

3. Po zastosowaniu herbicydowych cieczy jonowych w dawce 800 g substancji czynnej na ha pozostałości MCPA w ziarnie pszenicy ozimej były poniżej progu wykrywalności metody analitycznej (poniżej 0,005 mg/kg).

\section{Podziękowanie / Acknowledgements}

Podziękowania dla Pana prof. dr hab. inż. Juliusza Pernaka i jego zespołu badawczego z Politechniki Poznańskiej za przekazanie próbek herbicydowych cieczy jonowych do badań.

\section{Literatura / References}

Cojocaru O.A., Shamshina J.L., Gurau G., Syguda A., Praczyk T., Pernak J., Rogers R.D. 2013. Ionic liquid forms of the herbicide dicamba with increased efficacy and reduced volatility. Green Chemistry 15 (8): 2110-2120. DOI: 10.1039/C3GC37143C.

Dyrektywa Parlamentu Europejskiego i Rady 2009/128/WE z dnia 21 października 2009 r. ustanawiająca ramy wspólnotowego działania na rzecz zrównoważonego stosowania pestycydów (Dz. Urz. UE L 309/71 z dnia 24.11.2009 r.).

Heap I. 2017. http://weedscience.org/graphs/chronologicalincrease.aspx [Accessed: 17.05.2017].

Marcinkowska K. 2017. Pozostałości glifosatu w ziarnie i słomie oraz zdolność kiełkowania ziarna pszenicy jarej po zastosowaniu herbicydu w postaci cieczy jonowych w zabiegu przedżniwnym. [The residues of glyphosate in grain and straw of spring wheat and germination of grain after pre-harvest application of herbicides]. Progress in Plant Protecion/Postępy w Ochronie Roślin 57 (1): 95-100. DOI: 10.14199/ppp-2017-016.

Markiewicz B., Łęgosz B., Kordala-Markiewicz R., Walkiewicz F., Gwiazdowski R., Kubiak K., Praczyk T. 2013. Sole tebukonazolu i propikonazolu. Przemysł Chemiczny 92 (9): 1636-1639.

Pernak J., Markiewicz B., Zgoła-Grześkowiak A., Chrzanowski Ł., Gwiazdowski R., Marcinkowska K., Praczyk T. 2014a. Ionic liquids with dual pesticidal function. RSC Advances 4 (75): 39751-39754. DOI: 10.1039/C4RA04816D.

Pernak J., Niemczak M., Giszter R., Shamshina J.L., Gurau G., Cojocaru O.A., Praczyk T., Marcinkowska K., Rogers R.D. 2014b. Glyphosate-based herbicidal ionic liquids with increased efficacy. ACS Sustainable Chemistry and Engineering 2 (12): $2845-2851$. DOI: $10.1021 / \mathrm{sc} 500612 \mathrm{y}$.

Pernak J., Niemczak M., Materna K., Marcinkowska K., Praczyk T. 2013a. Ionic liquids as herbicides and plant growth regulators. Tetrahedron 69: 4665-4669. DOI: 10.1016/j.tet.2013.03.097.

Pernak J., Niemczak M., Shamshina J.L., Gurau G., Głowacki G., Praczyk T., Marcinkowska K., Rogers R.D. 2015. Metsulfuron-methyl-based herbicidal ionic liquids. Journal of Agricultural and Food Chemistry 63 (13): 3357-3366. DOI: 10.1021/jf505782p.

Pernak J., Niemczak M., Zakrocka K., Praczyk T. 2013b. Herbicidal ionic liquid with dual-function. Tetrahedron 69 (38): $8132-8136$.

Pernak J., Syguda A., Janiszewska D., Materna K., Praczyk T. 2011. Ionic liquids with herbicidal anions. Tetrahedron 67: 4838-4844.

Pernak J., Syguda A., Materna K., Janus E., Kardasz P., Praczyk T. 2012. 2,4-D based herbicidal ionic liquids. Tetrahedron 68 (22): $4267-4273$.

Polit J.T., Praczyk T., Pernak J., Sobiech Ł., Jakubiak E., Skrzypczak G. 2014. Inhibition of germination and early growth of rape seed (Brassica napus L.) by MCPA in anionic and ester form. Acta Physiologiae Plantarum 36 (3): 699-711. DOI 10.1007/s11738-013$-1448-x$. 
Praczyk T., Kardasz P., Jakubiak E., Syguda A., Materna K., Pernak J. 2012. Herbicidal ionic liquids with 2,4-D. Weed Science 60 (2): 189-192. DOI: https://doi.org/10.1614/WS-D-11-00171.1.

Praczyk T., Skrzypczak G. 2004. Herbicydy. PWRiL, Poznań, 274 ss.

Rozporządzenie Komisji (UE) nr 491/2014 z dnia 5 maja 2014 r. zmieniające załączniki II i III do Rozporządzenia (WE) nr 396/2005 Parlamentu Europejskiego i Rady w odniesieniu do najwyższych dopuszczalnych poziomów pozostałości ametoktradyny, azoksystrobiny, cykloksydymu, cyflutryny, dinotefuranu, fenbukonazolu, fenwaleratu, fludioksonilu, fluopyramu, flutriafolu, fluksapyroksadu, glufosynatu amonowego, imidachloprydu, indoksakarbu, MCPA, metoksyfenozydu, pentiopiradu, spinetoramu i trifloksystrobiny w określonych produktach lub na ich powierzchni.

Rozporządzenie Parlamentu Europejskiego i Rady (WE) nr 1107/2009 z dnia 21 października 2009 r. dotyczące wprowadzania do obrotu środków ochrony roślin i uchylające Dyrektywy Rady 79/117/EWG i 91/414/EWG.

Tomlin C.D.S. 2009. MCPA. p. 709-712. In: ”The Pesticide Manual: A World Compendium” (C.D.S. Tomlin, eds.), 14th ed. BCPC Publication, Hampshire, UK, 1457 pp.

Ustawa z dnia 8 marca 2013 r. o środkach ochrony roślin (Dz. U. z dnia 12 kwietnia 2013 r., poz. 455).

Zhu J., Ding G., Liu Y., Wang B., Zhang W., Guo M., Geng Q., Cao Y. 2015. Ionic liquid forms of clopyralid with increased efficacy against weeds and reduced leaching from soils. Chemical Engineering Journal 279: 472-477.

Zimdahl R.L.1999. Fundamentals of Weed Science. Academic Press - Elsevier Inc. USA, 556 pp. 